\title{
Symptoms of anxiety and depression and self-care behaviors during the COVID-19 pandemic in the general population
}

\author{
Oscar Galindo-Vázquez, ${ }^{1 *}$ Mónica Ramírez-Orozco, ${ }^{2}$ Rosario Costas-Muñiz, ${ }^{3}$ \\ Luis A. Mendoza-Contreras, ${ }^{1}$ Germán Calderillo-Ruíz ${ }^{4}$ and Abelardo Meneses-García ${ }^{5}$ \\ 'Instituto Nacional de Cancerología, Psycho-Oncology Department, Mexico City, Mexico; ${ }^{2}$ Universidad Nacional Autónoma de México, Faculty of \\ Psychology, Mexico City, Mexico; ${ }^{3}$ Memorial Sloan-Kettering Cancer Center, Department of Psychiatry and Behavioral Sciences, New York, United \\ States; ${ }^{4}$ Instituto Nacional de Cancerología, Internal Medicine Sub-directorate, Mexico City, Mexico; ${ }^{5}$ nstituto Nacional de Cancerología, General \\ Directorate, Mexico City, Mexico
}

\begin{abstract}
Introduction: The COVID-19 pandemic can have important psychosocial consequences in the population. Objective: To determine the levels anxiety and depression symptoms and self-care behaviors during the COVID-19 pandemic in the general population. Method: Online survey distributed over three weeks using a non-probability sampling. The PHQ-9 Patient Health Questionnaire, the GAD-7 Generalized Anxiety Disorder Scale and a self-care behaviors visual analogue scale were used. Between-group (anxiety and depression) descriptive and comparison analyses were carried out. Results: Out of 1508 included participants, $20.8 \%$ had symptoms of severe anxiety, while $27.5 \%$ showed symptoms of severe depression. Being a woman, being single, having no children, having medical comorbidities and a history of mental health care were associated with the presence of higher levels of anxiety and depression symptoms; 66 to $80 \%$ of the population complied with self-care recommendations. A need for receiving mental health care was identified in our study population. Conclusion: $A$ larger number of individuals with moderate to severe anxiety and depression symptoms were observed than in other pandemics. COVID-19 pandemic psychological effects are considered an emerging public mental health problem, and implementation of programs for their care is therefore recommended.
\end{abstract}

KEY WORDS: Anxiety. COVID-19. Depression. Pandemic.

\section{Síntomas de ansiedad, depresión y conductas de autocuidado durante la pandemia de COVID-19 en la población general}

\section{Resumen}

Introducción: La pandemia por COVID-19 puede tener consecuencias psicosociales importantes en la población. Objetivo: Determinar los niveles de síntomas de ansiedad, depresión y conductas de autocuidado durante la pandemia de COVID-19 en población general. Método: Encuesta en línea distribuida durante tres semanas mediante muestreo no probabilístico. Se empleó el Cuestionario sobre la Salud del Paciente PHQ-9, la Escala del Trastorno de Ansiedad Generalizada GAD-7 y la Escala análoga visual de conductas de autocuidado. Se realizaron análisis descriptivos y de comparación entre los grupos con ansiedad y depresión. Resultados: Se incluyeron 1508 participantes, 20.8 \% presentó síntomas de ansiedad grave y $27.5 \%$, síntomas de depresión grave. Ser mujer, soltero(a) no tener hijos, presentar comorbilidad médica y antecedentes de atención a la salud mental estuvieron relacionados con la presencia de mayores niveles de síntomas de ansiedad

Correspondence:

*Oscar Galindo-Vázquez

E-mail: psigalindo@yahoo.com.mx
Gac Med Mex. 2020;156:294-301

Contents available at PubMed

www.gacetamedicademexico.com 0016-3813/С 2020 Academia Nacional de Medicina de México, A.C.. Published by Permanyer. This is an open access article under the CC BY-NC-ND license (http://creativecommons.org/licenses/by-nc-nd/4.0/). 
y depresión; 66 a 80 \% de la población cumplía con las recomendaciones de autocuidado. Se identificó la necesidad de recibir atención de salud mental. Conclusión: Se observó mayor número de individuos con síntomas de ansiedad y depresión moderadas a graves que en otras pandemias. Los efectos psicológicos de la pandemia de COVID-19 se consideran un problema de salud mental pública emergente, por lo que se recomienda la implementación de programas para su atención.

PALABRAS CLAVE: Ansiedad. COVID-19. Depresión. Pandemia.

\section{Introduction}

The COVID-19 pandemic has brought not only the risk of transmission and infection-related death, but also important psychological effects. ${ }^{1}$ Psychological factors are known to play a vital role in the success of public health strategies that are used to control epidemics and pandemics, as well as in the communication of risks, vaccination and antiviral therapy, hygiene practices and social distancing. ${ }^{2-4}$

Pandemics, such as that of severe acute respiratory syndrome (SARS), have been reported to be stressful situations that threaten physical health and psychological well-being, in addition to causing disruptions in interpersonal functioning and the perception that transmission is relatively uncontrollable even when measures that reduce the risk are taken (for example, wearing masks, avoiding crowds). ${ }^{5}$

In viral outbreaks, a person with severe anxiety can misinterpret benign muscle aches or cough as signs of infection, as well as developing maladaptive behaviors such as compulsive handwashing, social withdrawal and panic shopping, which can have negative consequences for the individual and his/her community. For example, a sense of urgency for products that are needed for quarantine can lead to overspending in the storage of resources and harm to the community, which needs such resources for other purposes, including medical care. ${ }^{3}$ On the other hand, people who consider themselves to be at low risk of infection are unlikely to change their behavior and follow the social distancing recommendations, with the consequent negative impact on efforts to mitigate the dissemination of the virus.

With regard to reported psychological symptoms, mild anxiety was identified in $21.3 \%$ of 7143 college students exposed to COVID-19; in $2.7 \%$, moderate anxiety, and in $0.9 \%$, severe anxiety. Living in urban areas and with the parents were protective factors against anxiety. Having relatives or acquaintances infected with COVID-19, unstable financial situation and backlog in academic activities were associated with higher anxiety $(p<0.001)$. Social support was negatively correlated with the level of anxiety $(p<0.001){ }^{1}$

Moderate to severe or severe anxiety and/or depression symptoms were identified in $35 \%$ of 180 SARS survivors one month after recovery. Health workers or those who had relatives who died because of SARS were more likely to develop high levels of distress. $^{6}$

When hospital health workers $(n=82)$ were compared during the peak of the epidemic with hospital staff who recovered from SARS $(n=97)$, both groups were found to have the same level of concern about infecting others (especially their family members). Workers were more afraid of infection; in survivors, SARS-related fear was correlated with post-traumatic stress symptoms; in addition, they expressed concern about other health problems and discrimination $(p<$ 0.05). ${ }^{7}$ People who have experienced public health emergencies have varying degrees of stress, even after the event has ended or they have recovered and been discharged from hospital. ${ }^{6,8}$

Taking into account social interaction restrictions and confinement measures, mental health services have adopted the use of hotlines, mobile application platforms, the internet and social networks to share strategies for dealing with stress, ${ }^{9}$ as well as for assessing the psychosocial impact on exposed population. Therefore, the purpose of this research was to determine the levels of anxiety and depression symptoms, as well as self-care behaviors, during the COVID-19 pandemic in the general population.

\section{Method}

A non-experimental, cross-sectional study was carried out, ${ }^{10}$ for which an online survey was conducted using a non-probabilistic convenience sampling; 1508 male and female participants from Mexico and abroad were included. As inclusion criteria, a minimum age of 12 years and knowing how to read and write were considered. Individuals with cognitive impairment that prevented them from answering the survey were excluded, and those who during or after completing the 
survey decided not to continue participating were removed from the investigation.

An identification card was designed, which included sociodemographic and clinical data. The following evaluation instruments were used:

- Patient Health Questionnaire-9 (PHQ-9). The Patient Health Questionnaire-9 (PHQ-9), developed by Kroenke et al. in $2001,{ }^{11}$ is a screening tool that assesses the possible presence of major depressive disorder and the severity of depression symptoms. Its structure is one-dimensional, it has nine items based on Statistical Manual of Mental Disorders, Fourth edition, Text Revision (DSM IV TR) criteria and a global Cronbach's alpha of 0.89 . It was validated in the Mexican population,* with an internal consistency of 0.86 and an explained variance of $47 \%$.

- Generalized Anxiety Disorder-7 Scale (GAD-7). Developed by Spitzer et al. in $2006,{ }^{12}$ it is a screening tool that assesses the presence of possible generalized anxiety disorder. It has a one-dimensional structure of seven items based on DSM IV TR criteria, which explain $63 \%$ of variance, and a global Cronbach's alpha of 0.92 . It was validated in the Mexican population, ${ }^{*}$ with an internal consistency of 0.88 and an explained variance of $57.72 \%$.

- Self-care behaviors visual analogue scale. Behaviors were assessed using a 10-point visual analogue scale, where 0 means "I do not follow the recommendation at all" and 10 means "I follow the recommendation all the time", which specify how individuals carried out self-care strategies.

Sample collection was carried out from March 26 to April 12, 2020. The purpose of the investigation, its procedure, data confidentiality, as well possible risks and benefits, were explained to each participant by electronic means. All individuals voluntarily participated and granted written consent. The procedures of this investigation complied with the provisions of the Declaration of Helsinki with regard to research in human subjects.

Data were analyzed with SPSS version 22.0. Descriptive analysis of central tendency and dispersion

\footnotetext{
* Mendoza-Contreras L, Flores-Juárez J, Núñez-Hernández J, Guzmán Saldaña R, Lerma A. Galindo-Vázquez O. Propiedades psicométricas del Cuestionario sobre la Salud del Paciente (PHQ-9) y de la Escala del Trastorno de Ansiedad Generalizada (GAD-7) en población general mexicana. México: Servicio de Psicooncología, Instituto Nacional de Cancerología; 2020. Unpublished document.
}

measures was carried out to illustrate demographic and clinical characteristics, as well as univariate analysis to identify the differences between sociodemographic variables and the level of anxiety and depression symptoms. Normality of variables was determined by means of Kolmogorov-Smirnov goodness-of-fit test ( $p<0.001$ ), whereby a non-normal distribution was observed; therefore, medians and non-parametric Mann-Whitney $U$ and Kruskal-Wallis tests were used. ${ }^{13}$ Finally, Pearson's correlation analysis was carried out. A p-value $<0.05$ was established as statistically significant.

\section{Results}

As it can be observed in Table 1, total sample consisted of 1508 participants, 1,123 women and 385 men, with an average age of 34 years; $61.3 \%$ were childless, $50.8 \%$ were single, $55.2 \%$ had a college degree, $35.6 \%$ worked as professionals and $24 \%$ referred having some chronic degenerative disease.

Different behavioral areas related to the contingency and its psychosocial consequences were explored. Most participants (92\%) referred that they would undergo the test for COVID-19 detection, whereas $90 \%$ did not have any relative or friend with the virus infection at that moment.

Regarding self-care behaviors, adequate adherence to recommendations stood out, since $80 \%$ complied with not attending meetings or crowded places, $88 \%$ frequently washed or disinfected their hands, $66 \%$ kept the recommended distance (1.5 to $2 \mathrm{~m}$ ) and $72 \%$ stayed home.

As for coping strategies, $41 \%$ cared little about getting sick, approximately $15 \%$ were frequently worried about getting the disease, while $31 \%$ continually analyzed their bodily sensations, interpreting them as symptoms of the disease. Half the participants frequently used past stressing experience strategies to reduce fear and generated a list of activities to stay active; the same percentage claimed that they maintained an optimistic and objective attitude towards the situation, as well as to have support networks to talk and solve problems (Table 2).

As regards specific needs to face the current health problem, $68 \%$ answered that having information about the disease was essential, as well as knowing the health institutions they can attend and covering the economic needs for subsistence; $34 \%$ considered it necessary for the psychological aspect to be taken care of (Figure 1). 
Table 1. Characteristics of the surveyed individuals with regard to symptoms of depression and anxiety during the COVID-19 pandemic $(\mathrm{n}=1508)$

\begin{tabular}{|c|c|c|c|c|c|}
\hline \multicolumn{3}{|l|}{ Age (years) } & \multicolumn{3}{|l|}{ Mean $=34.46 ;$ range $18-82$} \\
\hline & $\mathrm{n}$ & $\%$ & & $n$ & $\%$ \\
\hline $\begin{array}{l}\text { Gender } \\
\text { Females } \\
\text { Males }\end{array}$ & $\begin{array}{c}1123 \\
385\end{array}$ & $\begin{array}{l}74.5 \\
25.5\end{array}$ & $\begin{array}{l}\text { Level of education } \\
\text { Basic education } \\
\text { High school }\end{array}$ & $\begin{array}{c}34 \\
209 \\
833\end{array}$ & $\begin{array}{l}2.3 \\
13.9 \\
55\end{array}$ \\
\hline $\begin{array}{l}\text { Country } \\
\text { Mexico } \\
\text { Other }\end{array}$ & $\begin{array}{c}1421 \\
87\end{array}$ & $\begin{array}{c}94.2 \\
5.8\end{array}$ & $\begin{array}{l}\text { College degree } \\
\text { Postgraduate } \\
\text { Other }\end{array}$ & $\begin{array}{c}833 \\
406 \\
26\end{array}$ & $\begin{array}{r}55.2 \\
26.9 \\
1.7\end{array}$ \\
\hline $\begin{array}{l}\text { Marital status } \\
\text { Single } \\
\text { Married } \\
\text { Widower } \\
\text { Divorced or separated } \\
\text { Cohabitation } \\
\text { Other }\end{array}$ & $\begin{array}{c}817 \\
397 \\
17 \\
111 \\
157 \\
9\end{array}$ & $\begin{array}{c}54.2 \\
26.3 \\
1.1 \\
7.4 \\
10.4 \\
0.6\end{array}$ & $\begin{array}{l}\text { Occupation } \\
\text { Homemaker } \\
\text { Student } \\
\text { Employee } \\
\text { Unemployed } \\
\text { Professional } \\
\text { Retired }\end{array}$ & $\begin{array}{c}58 \\
256 \\
254 \\
48 \\
356 \\
27\end{array}$ & $\begin{array}{r}5.8 \\
25.6 \\
25.4 \\
4.8 \\
5.6 \\
2.7\end{array}$ \\
\hline $\begin{array}{l}\text { Paternity } \\
\text { Yes } \\
\text { No }\end{array}$ & $\begin{array}{l}583 \\
925\end{array}$ & $\begin{array}{l}38.7 \\
61.3\end{array}$ & $\begin{array}{l}\text { Residence in Mexico }(n=1426) \\
\text { Mexico City } \\
\text { State of Mexico } \\
\text { Other states }\end{array}$ & $\begin{array}{l}688 \\
265 \\
473\end{array}$ & $\begin{array}{l}42.8 \\
18.6 \\
33.2\end{array}$ \\
\hline \multirow[t]{2}{*}{$\begin{array}{l}\text { Medical comorbidity }(n=417) \\
\text { Hypertension } \\
\text { Diabetes } \\
\text { Cancer } \\
\text { Depression } \\
\text { Anxiety } \\
\text { Other }\end{array}$} & \multirow[t]{2}{*}{$\begin{array}{c}85 \\
43 \\
29 \\
75 \\
116 \\
196\end{array}$} & \multirow[t]{2}{*}{$\begin{array}{c}20.4 \\
10.3 \\
7.0 \\
18 \\
27.8 \\
47.0\end{array}$} & $\begin{array}{l}\text { Disease } \\
\text { Yes } \\
\text { No } \\
\text { Health insurance } \\
\text { Yes } \\
\text { No }\end{array}$ & $\begin{array}{c}400 \\
1108\end{array}$ & $\begin{array}{l}26.5 \\
73.5\end{array}$ \\
\hline & & & $\begin{array}{l}\text { Prior mental health care } \\
\text { Yes } \\
\text { No }\end{array}$ & $\begin{array}{l}929 \\
579\end{array}$ & $\begin{array}{l}61.6 \\
38.4\end{array}$ \\
\hline
\end{tabular}

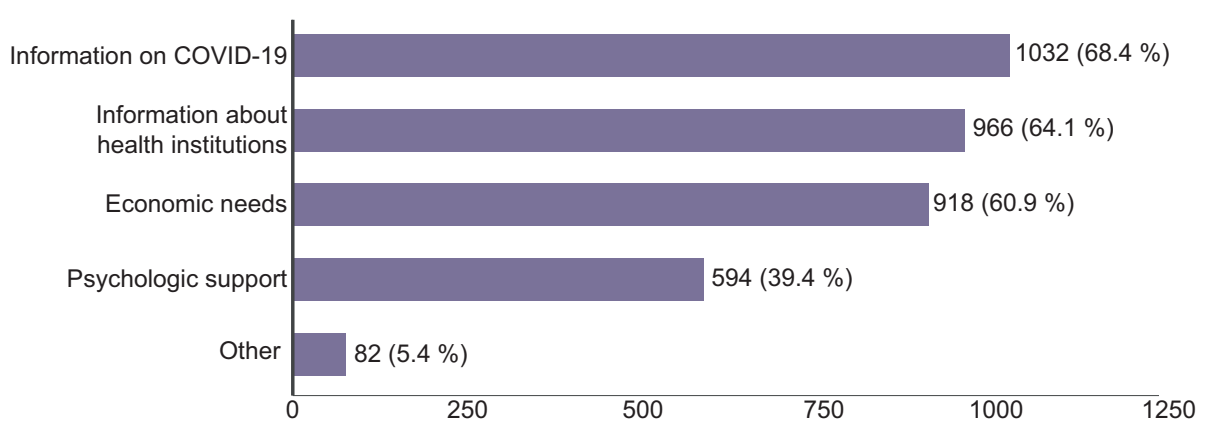

Figure 1. Perceived aspects for adapting to the COVID-19 pandemic.

The anxiety and depression symptom scores had means of 12.35 and 14.4 , respectively. The fact that $20.8 \%$ had symptoms of severe anxiety, and $27.5 \%$, of severe depression, stood out (Table 3). Participants without children, with medical conditions and a history of mental health care were observed to have higher levels of depression and anxiety $(p<0.001)$. Specifically, the female gender reported higher levels of anxiety, and single individuals, higher levels of depression $(p<0.001)$ (Tables 4 and 5).

It should be noted that there may be variability in each country's data, since the survey was conducted at different times according to the epidemiological phase of each nation. However, $88.4 \%$ of participants 
Table 2. Coping and self-care behaviors in the face of the COVID-19 pandemic in surveyed individuals with regard to symptoms of depression and anxiety

\begin{tabular}{|c|c|c|c|c|c|c|c|c|c|c|}
\hline & \multicolumn{2}{|c|}{ Never } & \multicolumn{2}{|c|}{ Rarely } & \multicolumn{2}{|c|}{ Frequently } & \multicolumn{2}{|c|}{ Almost always } & \multicolumn{2}{|c|}{ Always } \\
\hline & n & $\%$ & n & $\%$ & $\mathrm{n}$ & $\%$ & n & $\%$ & n & $\%$ \\
\hline How often do you worry about getting infected with COVID-19? & 7.4 & 6.9 & 629 & 41.7 & 523 & 34.7 & 164 & 10.9 & 81 & 5.4 \\
\hline $\begin{array}{l}\text { Are you continually analyzing and interpreting your bodily } \\
\text { sensations as symptoms of disease? }\end{array}$ & 329 & 21.8 & 704 & 46.7 & 340 & 22.5 & 84 & 5.6 & 51 & 3.4 \\
\hline Do you feel frustrated by the effects COVID-19 has had on your life? & 207 & 13.7 & 585 & 38.8 & 436 & 28.9 & 185 & 12.3 & 95 & 6.3 \\
\hline $\begin{array}{l}\text { When you are afraid, do you rely on experiences you have had in } \\
\text { similar situations to reduce fear? }\end{array}$ & 140 & 9.3 & 361 & 23.9 & 437 & 29.0 & 365 & 24.2 & 205 & 13.6 \\
\hline You generate a list of daily activities and try to keep busy & 138 & 9.2 & 302 & 20.0 & 390 & 25.9 & 390 & 25.9 & 288 & 19.1 \\
\hline $\begin{array}{l}\text { You maintain an optimistic and objective attitude towards the } \\
\text { situation }\end{array}$ & 20 & 1.3 & 134 & 8.9 & 423 & 28.1 & 521 & 34.5 & 410 & 27.2 \\
\hline \multirow{4}{*}{$\begin{array}{l}\text { You have someone you can lean on or with whom you can talk } \\
\text { about your problems }\end{array}$} & 40 & 2.7 & 200 & 13.3 & 244 & 16.2 & 341 & 22.6 & 683 & 45.3 \\
\hline & \multicolumn{10}{|c|}{ Visual analogue scale score } \\
\hline & \multicolumn{2}{|c|}{$0-1$} & \multicolumn{2}{|c|}{$2-3$} & \multicolumn{2}{|c|}{$4-5$} & \multicolumn{2}{|c|}{$6-7$} & \multicolumn{2}{|c|}{$8-10$} \\
\hline & $\mathrm{n}$ & $\%$ & $\mathrm{n}$ & $\%$ & n & $\%$ & $n$ & $\%$ & $\mathrm{n}$ & $\%$ \\
\hline $\begin{array}{l}\text { How much have you followed the following recommendations? } \\
\text { - Not attending social gatherings or crowded places } \\
\text { - Washing or disinfecting your hands frequently } \\
\text { - Keeping at least } 1.5 \mathrm{~m} \text { away from other people } \\
\text { - Staying home }\end{array}$ & $\begin{array}{l}44 \\
10 \\
64 \\
97\end{array}$ & $\begin{array}{l}2.9 \\
0.7 \\
4.3 \\
6.5\end{array}$ & $\begin{array}{l}44 \\
12 \\
46 \\
49\end{array}$ & $\begin{array}{l}2.9 \\
0.8 \\
3.3 \\
3.3\end{array}$ & $\begin{array}{c}82 \\
40 \\
167 \\
120\end{array}$ & $\begin{array}{c}5.4 \\
2.7 \\
11.1 \\
7.9\end{array}$ & $\begin{array}{c}92 \\
97 \\
225 \\
123\end{array}$ & $\begin{array}{c}6.8 \\
6.4 \\
26.3 \\
8.8\end{array}$ & $\begin{array}{l}1236 \\
1349 \\
1006 \\
1109\end{array}$ & $\begin{array}{l}82.0 \\
89.4 \\
66.8 \\
73.0\end{array}$ \\
\hline
\end{tabular}

Table 3. Level of COVID-19 pandemic-derived anxiety and depression

\begin{tabular}{|l|c|c|l|c|c|}
\hline Anxiety & \multicolumn{5}{|l|}{ Depression } \\
\hline Level & $\mathbf{n}$ & $\%$ & Level & n & $\%$ \\
\hline Minimal & 525 & 34.8 & Minimal & 598 & 39.7 \\
\hline Mild & 253 & 16.8 & Mild & 337 & 22.3 \\
\hline Moderate & 416 & 27.6 & Moderate & 158 & 10.5 \\
\hline Severe & 314 & 20.8 & Severe & 415 & 27.5 \\
\hline Total & 1508 & 100.0 & Total & 1508 & 100.0 \\
\hline
\end{tabular}

considered that they will experience negative repercussions in their individual economy.

A positive, middle-magnitude and statistically significant correlation was identified (Pearson's $r=0.721$, $p<0.001$ ), between the levels of depression and anxiety symptoms.

\section{Discussion}

The main strategies to fight coronavirus COVID-19 transmission involve self-care behaviors, which should be approached from a psychological perspective, since they require modification or implementation of behaviors in people who apparently have no immediate reinforcing mechanisms, which complicates their execution.

Higher levels of anxiety and depression were identified than those reported in the SARS and influenza pandemics, which denotes a larger effect on general population mental health. Belonging to the female gender, not having children, a single marital status, medical comorbidity and a history of mental health care coincided with the variables indicated in the literature as being related to the presence of greater psychological symptoms; in addition, economic concerns, repercussions of the pandemic on daily life and academic backlog were identified. ${ }^{1}$ The presence of a medical condition was reported by $26.5 \%$ of the sample, mainly of a cardiometabolic nature, which means that this group is at higher risk of becoming seriously ill with COVID-19 ${ }^{14}$, and during the pandemic it might face difficulties for obtaining adequate treatment. ${ }^{9}$

One possible explanation for high levels of anxiety and depression is high exposure to information about COVID-19, which Avittey associates with constant 
Table 4. Sociodemographic variables comparison between participants with symptoms of anxiety $(n=1508)$

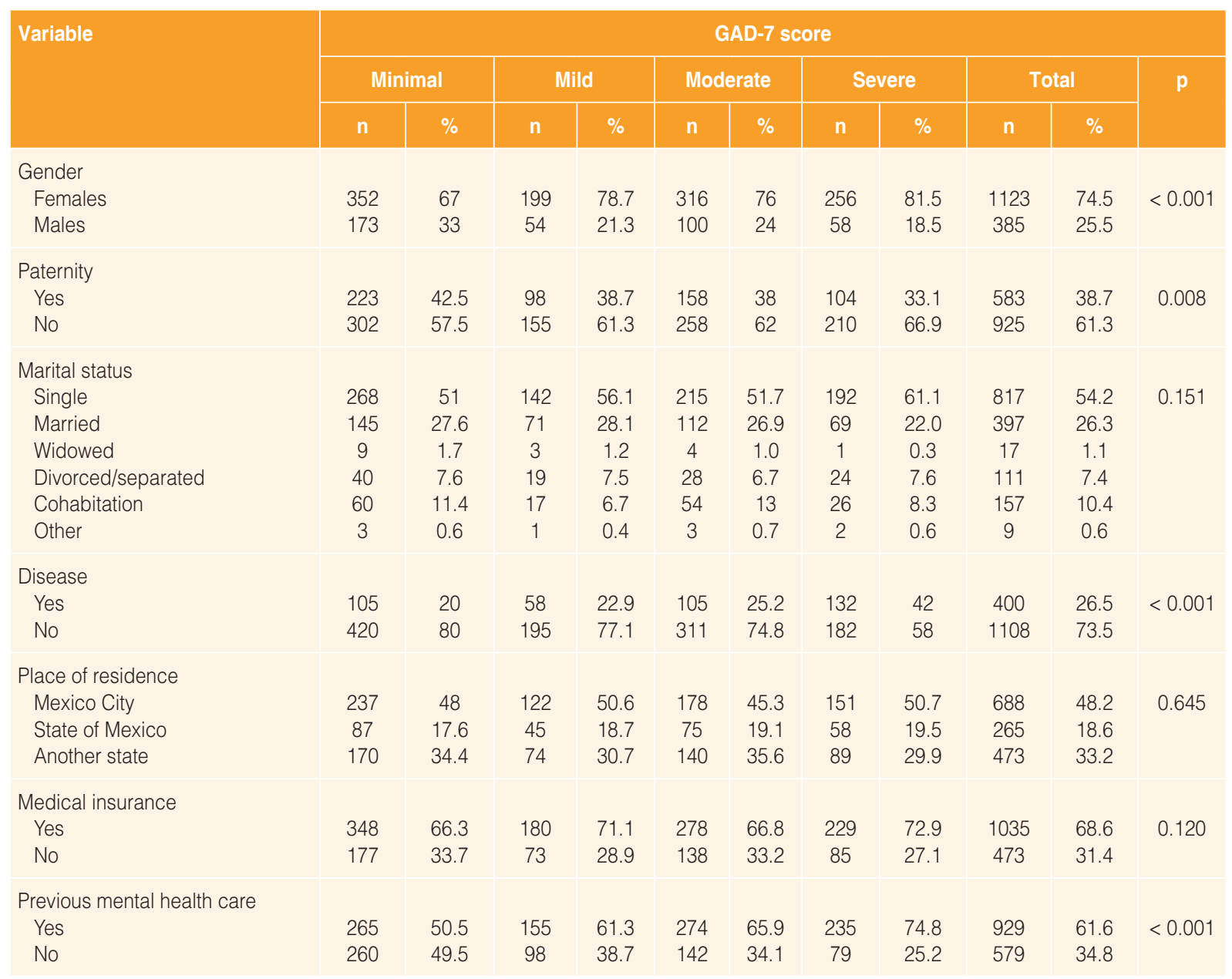

GAD-7 = Generalized Anxiety Disorder-7.

exposure to overwhelming news headlines and misinformation. ${ }^{15}$

A need for general information about the health institutions people can resort to was identified, as well as concern about the effects of the COVID-19 pandemic on the economy. Family income instability or decrease has been identified as a significant factor in anxiety during the crisis. ${ }^{16}$

Even though acceptable adherence to health recommendations was recorded in the present study, $5.8 \%$ did not stay away from meetings, $7.4 \%$ did not keep appropriate distance from people and $9.8 \%$ continued to leave home, a situation that entails repercussions on public health, since dissemination and transmission of the virus increases inasmuch as confinement and social distancing strategies are not followed.

Finally, although adequate psychological strategies to cope with the COVID-19 pandemic were identified, half the participants did not have such tools or conditions to adapt to the situation; therefore, it is necessary to focus on the population particular needs and cover them to help improve coping strategies. Receiving mental health care was considered necessary by $24 \%$ of participants; however, $72 \%$ did not have any remote care service, either by phone or online.

It is relevant to consider recommendations such as those reported by $\mathrm{Li}^{9}{ }^{9}$ who claims that the population exposed to COVID-19 can be classified in four levels:

1. People who are more vulnerable to mental health problems, such as hospitalized patients with confirmed infection or serious physical condition, frontline health professionals, and administrative personnel.

2. Isolated patients and in clinics with atypical infection symptoms.

3. Individuals with level 1 and 2 contacts, i.e., family members, colleagues, friends, and rescue workers. 
Table 5. Sociodemographic variables comparison between participants with symptoms of depression $(n=1508)$

\begin{tabular}{|c|c|c|c|c|c|c|c|c|c|c|c|}
\hline \multirow[t]{3}{*}{ Variable } & \multicolumn{11}{|c|}{ PHQ-9 score } \\
\hline & \multicolumn{2}{|c|}{ Minimum } & \multicolumn{2}{|c|}{ Mild } & \multicolumn{2}{|c|}{ Moderate } & \multicolumn{2}{|c|}{ Severe } & \multicolumn{2}{|c|}{ Total } & \multirow[t]{2}{*}{$p$} \\
\hline & $\mathrm{n}$ & $\%$ & $\mathrm{n}$ & $\%$ & $\mathrm{n}$ & $\%$ & $\mathrm{n}$ & $\%$ & $\mathrm{n}$ & $\%$ & \\
\hline \multicolumn{12}{|l|}{ Gender } \\
\hline Females & 429 & 71.7 & 247 & 73.3 & 127 & 80.4 & 320 & 77.1 & 1123 & 74.5 & 0.024 \\
\hline Males & 169 & 28.3 & 90 & 26.7 & 31 & 19.6 & 95 & 22.9 & 385 & 25.5 & \\
\hline \multicolumn{12}{|l|}{ Paternity } \\
\hline Yes & 285 & 47.7 & 124 & 36.8 & 51 & 32.3 & 123 & 29.6 & 583 & 38.7 & $<0.001$ \\
\hline No & 313 & 52.3 & 213 & 63.2 & 107 & 67.7 & 292 & 70.4 & 925 & 61.3 & \\
\hline \multicolumn{12}{|l|}{ Marital status } \\
\hline Single & 274 & 45.8 & 175 & 51.9 & 95 & 60.1 & 273 & 65.8 & 817 & 54.2 & $<0.001$ \\
\hline Married & 196 & 32.8 & 94 & 27.9 & 39 & 24.7 & 68 & 16.4 & 397 & 26.3 & \\
\hline Widowed & 10 & 1.7 & 1 & 0.3 & 0 & 0.0 & 6 & 1.4 & 17 & 1.1 & \\
\hline Divorced/separated & 45 & 7.5 & 23 & 6.8 & 9 & 5.7 & 34 & 8.2 & 111 & 7.4 & \\
\hline Cohabitation & 69 & 11.5 & 42 & 12.5 & 14 & 8.9 & 32 & 7.7 & 157 & 10.4 & \\
\hline Other & 4 & 0.7 & 2 & 0.6 & 1 & 0.6 & 2 & 0.5 & 9 & 0.6 & \\
\hline \multicolumn{12}{|l|}{ Disease } \\
\hline Yes & 117 & 19.6 & 80 & 23.7 & 46 & 29.1 & 157 & 37.8 & 400 & 26.5 & $<0.001$ \\
\hline No & 481 & 80.4 & 257 & 76.3 & 112 & 70.9 & 258 & 62.2 & 1108 & 73.5 & \\
\hline \multicolumn{12}{|l|}{ Place of residence } \\
\hline Mexico City & 278 & 48.7 & 149 & 47.2 & 67 & 46.5 & 194 & 49.1 & 688 & 48.2 & 0.173 \\
\hline State of Mexico & 95 & 16.6 & 54 & 17.1 & 39 & 27.1 & 77 & 19.5 & 265 & 18.6 & \\
\hline Another state & 198 & 34.7 & 113 & 35.8 & 38 & 26.4 & 124 & 31.4 & 473 & 33.2 & \\
\hline \multicolumn{12}{|l|}{ Health insurance } \\
\hline Yes & 421 & 70.4 & 232 & 68.8 & 113 & 71.5 & 269 & 64.8 & 1035 & 68.6 & 0.100 \\
\hline No & 177 & 29.6 & 105 & 31.2 & 45 & 28.5 & 146 & 35.2 & 473 & 31.4 & \\
\hline \multicolumn{12}{|l|}{ Prior mental health care } \\
\hline Yes & 296 & 49.5 & 224 & 66.5 & 106 & 67.1 & 303 & 73 & 929 & 61.6 & $<0.001$ \\
\hline No & 302 & 50.5 & 113 & 33.5 & 52 & 32.9 & 112 & 27 & 579 & 38.4 & \\
\hline
\end{tabular}

PHQ-9 = Patient Health Questionnaire-9

4. People affected by epidemic prevention and control measures, susceptible people and the general population.

Among the limitations, it should be noted that the sample was collected by convenience and that a cross-sectional research design was used; therefore, making a prospective follow-up is suggested, which will allow changes in symptoms and safety measures to be observed as the public health situation is modified.

\section{Conclusions}

Mental health problems in the general population during the COVID-19 pandemic represent a challenge for the public health system; therefore valid and reliable psychosocial interventions are required to timely identify the onset and intensity of symptoms of depression and anxiety, as well as to assess the effects of clinical and community psychosocial interventions.

\section{Conflict of interests}

The authors declare that they have no conflicts of interest.

\section{Funding}

The authors did not receive any sponsoring to carry out this article.

\section{Ethical disclosure}

Protection of people and animals. The authors declare that no experiments were performed on humans or animals for this research.

Confidentiality of data. The authors declare that they have followed the protocols of their work center on the publication of patient data. 
Right to privacy and informed consent. The authors obtained informed consent from the participants referred to in the article. This document is in the possession of the corresponding author.

\section{References}

1. Cao W, Fang Z, Hou G, Han M, Xu X, Dong J, et al. The psychological impact of the COVID-19 epidemic on college students in China. Psychiatry Res. 2020;287:112934.

2. Taylor S, Asmundson GJ. Treating health anxiety: a cognitive-behavioral approach. USA: Guilford; 2004.

3. Asmundson GJ, Taylor S. How health anxiety influences responses to viral outbreaks like COVID-19: what all decision-makers, health authorities, and health care professionals need to know. J Anxiety Disord. 2020;71:102211.

4. Wheaton MG, Abramowitz JS, Berman NC, Fabricant LE, Olatunji BO Psychological predictors of anxiety in response to the H1N1 (swine flu) pandemic. Cognit Ther Res. 2012;36:210-218.

5. Gan Y, Liu Y, Zhang Y. Flexible coping responses to severe acute respiratory syndrome-related and daily life stressful events. Asian J Soc Psychol. 2004;7:55-66.
6. Cheng SK, Wong CW, Tsang J, Wong KC. Psychological distress and negative appraisals in survivors of severe acute respiratory syndrome (SARS). Psychol Med. 2004;34:1187-1195.

7. Ho SM, Kwong-Lo RS, Mak CW, Wong JS. Fear of severe acute respiratory syndrome (SARS) among health care workers. J Consulting Clin Psychol. 2005;73:344-349.

8. Fan $\mathrm{F}$, Long $\mathrm{K}$, Zhou $\mathrm{Y}$, Zheng $\mathrm{Y}$, Liu $\mathrm{X}$. Longitudinal trajectories of post-traumatic stress disorder symptoms among adolescents after the Wenchuan earthquake in China. Psychol Med. 2015;45:2885-2896.

9. Li W, Yang Y, Liu ZH, Zhao YJ, Zhang Q, Zhang L, et al. Progression of mental health services during the COVID-19 outbreak in China. Int $J$ Biol Sci. 2020;16:1732-1738.

10. Babbie E. Fundamentos de la investigación social. Mexico: International Thomson; 2000.

11. Kroenke K, Spitzer RL Williams JBW. The PHQ-9: validity of a brief depression severity measure. J Gen Intern Med. 2001;16:606-613.

12. Spitzer RL, Kroenke K, Williams JBW, Löwe B. A brief measure for assessing generalized anxiety disorder: The GAD-7. Arch Intern Med. 2006;166:1092-1097.

13. Juárez F, Villatoro J, López E. Apuntes de estadística inferencial. Mexico: Instituto Nacional de Psiquiatría Ramón de la Fuente; 2002.

14. Centers for Disease Control and Prevention [Internet]. USA: Coronavirus disease 2019; 2020

15. Ayittey FK, Ayittey MK, Chiwero NB, Kamasah JS, Dzuvor C. Economic impacts of Wuhan 2019-nCoV on China and the world. J Med Virol. 2020;92.

16. Liu ZF. A study on the relationship between adverse family experiences in childhood and emotional and anxiety disorders. Dalian Medical University; 2013. 